\title{
ANALISIS PENGGUNAAN INTERNET TERHADAP KARAKTER BERSAHABAT/KOMUNIKATIF PADA PEMBELAJARAN BIOLOGI
}

\author{
Ika Chastanti ${ }^{*}$ Maharani Gultom, Novi Fitriandika Sari \\ FKIP Universitas Labuhan Batu, Jalan SM Raja No. 126 A, Aek Tapa, Rantauprapat \\ *Korespondensi Author: halim@unimed.ac.id
}

\section{INFO ARTIKEL}

Histori Artikel

Received 22 Nopember 2019

Revised 30 Januari 2020

Accepted 6 Febuari 2020

Published 18 Febuari 2020

Keywords:

Bersahabat/Komunikatif, Internet, Pembelajaran Biologi

\begin{abstract}
ABSTRAK
Kemajuan teknologi yang semakin pesat memberikan dampak positif dan negatif terhadap karakter siswa. Salah satu dampak negatif penggunaan internet yaitu berkurangnya kemampuan bersahabat/komunikasi siswa dalam kehidupan sehari-hari. Siswa lebih memilih untuk mengakses media sosial daripada harus berkomunikasi langsung dengan orang di sekitarnya. Tujuan penelitian ini untuk mengetahui penggunaan internet di kalangan siswa terhadap karakter bersahabat/komunikatif dalam pembelajaran biologi. Penelitian ini merupakan penelitian kualitatif yang mana In-depth Interview sebagai sumber data utama, dan angket sebagai sumber data sekunder. Teknik sampling yang digunakan adalah Purposive sampling. Sampel dari penelitian ini adalah siswa SMA dan Guru Biologi. Hasil penelitian menunjukkan bahwa karakter bersahabat/komunikatif belum terbentuk dengan baik $(28,89 \%)$ siswa menjawab kadang-kadang. Peranan guru juga kurang maksimal dalam menanamkan karakter bersahabat/komunikatif. Guru juga lebih memilih untuk mengakses internet ketika proses pembelajaran biologi berlangsung. Penanaman nilai karakter bersahabat/komunikatif dibutuhkan peran orang tua. Peranan orang tua juga belum maksimal untuk membentuk karakter ketika siswa berada di rumah. Orang tua membolehkan siswa mengakses internet dan tidak ada batasan waktu dalam penggunaannya sehingga komunikasi langsung antara orang tua dan siswa tidak terjalin dengan baik.
\end{abstract}

\section{ABSTRACT}

Technological advances that are increasingly rapid have a positive and negative impact on the character of students. One of the negative effects of using the internet is that it is reduced to the ability to communicate / communicate with students in daily life. Students prefer to access social media rather than having to communicate directly with those around them. The purpose of this study is to find out the internet usage among students towards communicative / communicative character in biology learning. This study is a qualitative study in which in-depth interviews are the main data source, and questionnaires as secondary data sources. The sampling technique used is Purposive sampling. The samples from this study were high school students and Biology teachers. The results of the study show that friendly characters / if communicities have not been well established (28.89\%) students answer sometimes. The role of the teacher is also not maximal in instilling friendly / communicative characters. Teachers also prefer to access the internet when the biology learning process takes place. The cultivation of friendly / communicative character values requires the role of parents. The role of parents is also not maximal to shape character when students are at home. Parents allow students to access the internet and there is no time limit in their use so that direct communication between parents and students is not well established.

Copyright (C 2019 Universitas Negeri Medan. Artikel Open Access dibawah lisensi CCBY-4.0 (https://creativecommons.org/licenses/by/4.0) 
How To Cite:

Chastanti, I., Gultom, M., \& Sari, NF. (2019). Analisis Penggunaan Internet Terhadap Karakter Bersahabat/Komunikatif Pada Pembelajaran Biologi. Jurnal Pelita Pendidikan, 7(4), 178-184.

\section{PENDAHULUAN}

Kemajuan teknologi sangat penting untuk kehidupan manusia. Teknologi harus terus dikembangkan sebagai upaya untuk terus mencari inovasi. Salah satu contoh kemajuan teknologi adalah internet. Pengguna internet saat ini semakin meningkat. Internet sebagai sebuah jaringan besar yang menghubungkan jaringan komputer baik dari organisasi bisnis, organisasi pemerintahan, dan sekolahsekolah dari seluruh dunia secara langsung dan cepat (Turban, Rainer, \& Potter, 2005). Pengguna internet mencakup semua kalangan baik anak-anak maupun dewasa. pengguna internet di seluruh dunia telah mencapai angka 31,7 miliar dan dari tahun ke tahun jumlah pengguna internet tumbuh hingga 7,6 persen. Sedangkan untuk pengguna media sosial sendiri mencapai angka 2,2 miliar dengan pengguna mencapai 3,7 miliar (Noviandari, 2015).

Riset yang dipublikasikan oleh Crowdtap, Ipsos MediaCT, dan The Wall Street Journal pada tahun 2014 melibatkan 839 responden dari usia 16 hingga 36 tahun menunjukkan bahwa jumlah waktu yang dihabiskan khalayak untuk mengakses internet dan media sosial mencapai 6 jam 46 menit per hari, melebihi aktivitas untuk mengakses media tradisional (Nasrullah, 2015). Kebutuhan akan menjalin hubungan sosial di internet merupakan alasan utama yang dilakukan oleh khalayak dalam mengakses media. Kondisi ini tidak bisa didapatkan ketika khalayak mengakses media tradisional (Mulawarman dan Nurfitri, 2017).

Media sosial merupakan contoh penggunaan internet yang bisa diakses semua kalangan usia. Media sosial mengajak semua orang untuk bergabung memberikan komentar, pendapat, serta membagi informasi dengan cepat dengan waktu yang tidak terbatas. Bagi masyarakat khususnya kalangan remaja, media sosial sudah menjadi candu yang membuat penggunanya tiada hari tanpa membuka media sosial.

Kalangan remaja yang mempunyai media sosial biasanya memposting tentang kegiatan pribadinya, curhatannya, serta foto-foto bersama teman. Hal ini dikarenakan dalam internet khususnya media sosial sangat mudah memalsukan jati diri atau melakukan kejahatan. saat ini seringkali remaja beranggapan bahwa semakin aktif dirinya di media sosial maka mereka akan semakin dianggap keren dan gaul. Sedangkan remaja yang tidak mempunyai media sosial biasanya dianggap kuno atau ketinggalan jaman dan kurang bergaul (Putri, et al, 2017).

Anak-anak yang selalu menggunakan media sosial biasanya memiliki kecenderungan susah untuk bersosialisasi, sehingga pembentukan karakter bersahabat dalam pembelajaran biolgi tidak akan tercapai, ketika anak bertemu dengan temannya maka mereka akan sibuk dengan "gadget" masing-masing sehingga tidak terbentuk komunikasi yang baik. Bersahabat adalah sikap atau tindakan yang berhubungan dengan orang lain yang didalamnya terdapat komunikasi yang mudah dimengerti sehingga terwujud suasana yang menyenangkan dalam bekerjasama (Prigunanto, 2015).

Karakter besahabat/komunikatif menunjukkan kemampuan seseorang dalam menyampaikan ide atau hasil pemikiran 
kepada orang lain dalam bergaul. Karakter ini menjadi modal penting dalam kehidupan bermasyarakat. Seseorang yang bersahabat/komunikatif adalah orang yang mudah bergaul dengan orang lain dan biasanya selain mampu menyampaikan, juga mampu mendengarkan apa yang disampaikan oleh orang lain untuk kemudian direspon dengan cara yang tepat. Indicator bersahabat/komunikatif di sekolah dan kelas menurut Kemendiknas (2009) adalah (1) Suasana sekolah yang memudahkan terjadinya interaksi antar warga sekolah; (2) Berkomunikasi dengan bahasa yang santun; (3) Saling menghargai dan menjaga kehormatan; (4) Pergaulan dengan cinta kasih dan rela berkorban; (5) Tidak menjaga jarak dan membeda-bedakan dalam komunikasi.

Berdasarkan uraian di atas, maka penelitian ini dilakukan untuk mengetahui penggunaan internet terhadap karakter bersahabat/komunikatif siswa dalam pembelajaran biologi. Hal ini perlu dilakukan agar siswa dapat lebih mengembangkan kemampuan interpersonal dalam kehidupan sehari-hari.

\section{METODE PENELITIAN}

Penelitian ini dilaksanakan mulai bulan Februari 2019 - Juni 2019 di SMA Kabupaten Labuhanbatu Utara. Model pendekatan yang dilakukan dalam penelitian ini adalah metode kualitatif. Pendekatan kualitatif dilakukan melalui teknik pengumpulan data dengan wawancara mendalam (In-depth interview) dengan sasaran informan yang memiliki kapasitas sesuai dengan kebutuhan penelitian dan pemberian kuesioner kepada siswa untuk mengetahui karakter bersahabat/komunikatif. Pengertian kapasitas disini adalah orang yang mengerti dan menguasai informasi tentang situasi, kondisi, atau kehidupan di sekitar lokasi penelitiana. Teknik sampling dalam penelitian ini adalah Stratified Random Sampling yang mana yang dijadikan sampel adalah SMA yang berada di pusat kota, tengah, dan ujung dari Kabupaten Labuhanbatu Utara. Teknik analisis data dilakukan secara deskriptif kualitatif dengan menggunakan model Miles dan Huberman. Model ini dilakukan dalam 3 tahap: (1) Reduksi data yaitu (a) meringkaskan data kontak langsung dengan orang, kejadian dan situasi di lokasi penelitian, (b) pengkodean, (c) pembuatan catatan objetif, (d) membuat catatan reflektif, (e) membuat catatan marginal, (f) penyimpana data, (g) pembuatan memo, (h) analisis antarlokasi, dan (i) pembuatan ringkasan sementara antar lokasi. Tahap (2) Display Data dengan menyusun teks naratif, Tahap (3) Verifikasi yaitu tahap penarikan kesimpulan.

\section{HASIL DAN PEMBAHASAN}

Analisis Karakter Bersahabat/Komunikatif Siswa

Indikator karakter bersahabat/komunikatif ada 5 yaitu (1) Suasana Sekolah; (2) Komunikasi dengan Bahasa Santun; (3) Saling Menghargai; (4) Pergaulan yang baik; dan (5) Tidak Menjaga Jarak. Hasil analisis angket yang diberikan kepada siswa dapat dilihat pada Tabel 1. 
Tabel 1. Persentase Karakter Bersahabat/Komunikasi Siswa dalam Pembelajaran Biologi

\begin{tabular}{|c|c|c|c|c|c|}
\hline \multirow[t]{2}{*}{ No } & \multirow[t]{2}{*}{ Indikator } & \multicolumn{4}{|c|}{ Kategori Karakter Bersahabat/Komunikatif Siswa } \\
\hline & & Selalu & Sering & $\begin{array}{l}\text { Kadang } \\
\text { Kadang }\end{array}$ & Tidak Pernar \\
\hline 1. & Suasana Sekolah & $24,00 \%$ & $46,75 \%$ & $12,55 \%$ & $16,67 \%$ \\
\hline 2. & $\begin{array}{l}\text { Komunikasi } \\
\text { dengan Bahasa } \\
\text { Santun }\end{array}$ & $24,56 \%$ & $24,50 \%$ & $16,72 \%$ & $34,22 \%$ \\
\hline 3. & $\begin{array}{l}\text { Saling } \\
\text { Menghargai }\end{array}$ & $42,32 \%$ & $21,56 \%$ & $25,07 \%$ & $11,05 \%$ \\
\hline 4. & $\begin{array}{l}\text { Pergaulan yang } \\
\text { Baik }\end{array}$ & $23,85 \%$ & $22,69 \%$ & $28,89 \%$ & $25,07 \%$ \\
\hline 5. & $\begin{array}{l}\text { Tidak Menjaga } \\
\text { Jarak }\end{array}$ & $12,66 \%$ & $32,56 \%$ & $39,03 \%$ & $15,75 \%$ \\
\hline & Rata-Rata & $30,75 \%$ & $29,61 \%$ & $19,18 \%$ & $20,55 \%$ \\
\hline
\end{tabular}

Indikator suasana sekolah $46,75 \%$ siswa menjawab sering. Pada indicator ini siswa mengatakan bahwa suasana sekolah membuat siswa merasa nyaman. Guru menggunakan bahasa yang santun ketika pembelajaran biologi berlangsung, guru berusaha untuk menggunakan kalimat yang mudah dimengerti oleh siswa, sehingga suasana pembelajaran menjadi menyenangkan. Akan tetapi, ketika guru marah membuat siswa merasa tidak nyaman karena guru biasanya menggunakan katakata yang kasar. Jika ada siswa yang melakukan kesalahan atau tidak mengerjakan pekerjaan rumah, maka guru biasanya akan marah dengan mengeluarkan kata-kata yang seharusnya tidak boleh diucapkan oleh seorang pendidik. Keberadaan sekolah menengah atas sebagai wahana bersosialisasi dengan sahabat, keluarga, relasi, seolah-olah membuat orang semakin dekat dan akrab satu dengan yang lain. (Prisgunanto, 2015).

Indikator komunikasi dengan bahasa santun diperoleh jawaban siswa dengan persentase $34.22 \%$ menjawab tidak pernah. Pada kondisi ini, siswa biasanya berkomunikasi dengan menggunakan bahasa yang kurang santun. Siswa hanya berkomunikasi dengan teman yang dikenalnya saja, jika bertemu dengan teman dari kelas lainnya, maka siswa biasanya tidak menyapa siswa, bahkan sisw cenderung mengejek siswa tersebut.

Indikator saling menghargai diperoleh hasil bahwa sebanyak 42,32\% siswa menjawab selalu. Pada indiaktor ini, siswa menghargai temannya ketika diberi tugas kelompok oleh guru biologi. Siswa mendengarkan dengan baik pendapat yang disampaikan oleh teman kelompoknya.

Indikator pergaulan yang baik sebanyak 28,89\% siswa menjawab kadangkadang. Indicator ini sinkron dengan jawaban siswa pada indicator komunikasi dengan bahasa santun karena siswa lebih memilih berteman dengan orang yang dikenalnya saja. Indikator tidak menjaga jarak didapatkan jawaban siswa sebanyak 39,03\% (kadang-kadang). Pada indicator ini, siswa biasanya tidak menatap wajah temannya ketika berkomunikasi. Siswa lebih memilih untuk melihat "gadget" dibandingkan harus berkomunikasi dengan temannya. 
Analisis Peran Orang Tua Terhadap Karakter Bersahabat/Komunikatif

Orang tua memiliki peran terhadap pembentukan karakter bersahabat/komunikatif siswa. Peranan orang tua dalam penelitian ini adalah (1) Penggunaan internet di rumah; (2) Komunikasi dengan orang tua; (3) Fasilitas Internet di rumah; dan (4) Penggunaan smartphone ketika kumpul keluarga, dapat dilihat di bawah ini (Gambar 1).

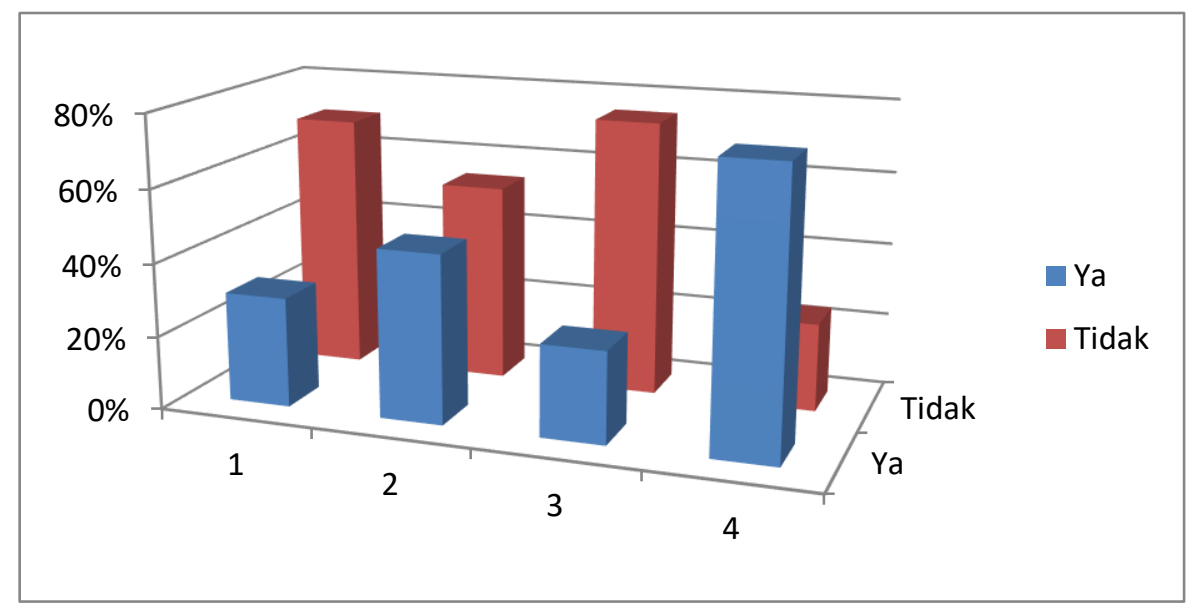

Gambar 1. Peranan Orang tua terhadap Karakter Bersahabat/Komunikatif

Hasil menunjukkan bahwa peranan orang tua masih belum maksimal untuk membentuk karakter bersahabat/komunikatif siswa. Pada Peranan orang tua dalam (1) penggunaan internet di rumah diperoleh dengan persentase $70 \%$ menjawab tidak yang menunjukkan bahwa orang tua tidak memberi batasan waktu dalam penggunaan internet di rumah. (2) Komunikasi dengan orang tua belum terjalin dengan baik dengan persentase $54 \%$ siswa menjawab tidak. (3) Penyediaan fasilitas internet di rumah, siswa menjawab tidak (75\%) yang menunjukkan bahwa di rumah siswa tidak diberi fasilitas internet (wi-fi) tetapi siswa selalu diberikan uang untuk isi ulang paket internet. (4) Peranan orang tua ketika kumpul dengan semua anggota keluarga menunjukkan bahwa 76\% siswa boleh menggunakan smarphone, yang artinya ketika kumpul keluarga, maka komunikasi tidak terjalin dengan baik karena anggota keluarga sibuk dengan smartphonenya.

$$
\text { Perkembangan internet }
$$

membawa dampak positif dan negatif bagi yang menggunakannya. Berdampak positif jika internet digunakan sesuai dengan porsinya yaitu sebagai wadah untuk mencari informasi terbaru yang diinginkan yang berhubungan dengan ilmu pengetahuan. Internet akan berdampak negatif jika pengguna hanya mengakses media sosial untuk posting hal-hal yang bersifat pribadi, memberikan komentar negatif kepada akun tertentu. Kenyataan yang terjadi saat ini adalah semakin banyaknya kalangan remaja yang mempunyai akun media sosial dan mereka sibuk dengan untuk melihat gadget mereka. Jika hal ini terus terjadi maka kemampuan berkomunikasi siswa akan terganggu karena siswa lebih memilih untuk sibuk dengan dunia "maya" yang mereka anggap sudah seperti dunia nyata.

Program pendidikan karakter dapat memberikan efek yang positif pada perkembangan karakter dan prestasi akademik (Katilmis, et al., 2011). Pendidikan karakter menunjukkan sebuah hubungan antara tingkah laku negatif dan hasil akademik yaitu ketika tingkah laku negatif menurun maka hasil akademik meningkat. Dalam konteks pendidikan formal di sekolah, bisa jadi salah satu penyebabnya karena pendidikan di Indonesia lebih menitik beratkan kepada pengembangan intelektual atau kognitif, sedangkan aspek soft skill atau non akademik sebagai unsur utama pendidikan moral belum diperhatikan.

Hasil analisis angket yang telah diberikan kepada siswa menunjukkan bahwa karakter bersahabat/komunikatif siswa belum terbentuk dengan baik karena siswa menyukai berkomunikasi dengan dunia maya dibandingkan berkomunikasi 
langsung dengan menatap wajah temannya. Perilaku siswa ini terjadi selama di sekolah, ketika jam istirahat, semua siswa akan sibuk dengan smartphone masing-masing ketika siswa berkumpul di kantin. Peraturan sekolah yang melarang siswa membawa smartphone ternyata diabaikan oleh siswa, dan siswa pun jarang mendapat hukuman ketika mereka membawa smartphone. Sekolah tidak serius dalam menanggapi penggunaan internet berlebihan di sekolah. Sekolah melakukan razia smartphone hanya pada hari-hari tertentu saja, tidak setiap hari dilakukan sehingga masih banyak ditemukan siswa yang membawa smartphone. Ketika razia dilakukan, siswa biasanya akan menitipkan smartphone mereka ke kantin sekolah atau mereka sembunyikan di tempat yang menurut mereka aman.

Kemajuan di bidang teknologi seperti internet sebenarnya dapat mempengaruhi perilaku atau akhlak seseorang atau dengan kata lain perilaku seseorang ditentukan oleh hasil-hasil perilaku. Hal ini menjadikan manusia kehilangan kemanusiaannya dan hanya mengarah pada kesenangan dan kenikmatan saja, manusia akan lalai atau terbuai dengan teknologi, sehingga mereka melupakan kehidupan sosialnya di dunia nyata (Putro, 2005). Guru dan kepala sekolah merupakan komponen yang sangat menentukan proses pendidikan. Adanya komunikasi, koordinasi dan kerjasama yang saling berkesinambungan akan menciptakan lingkungan pendidikan yang kondusif (Fathoni dan Desstya, 2017).

Sejalan dengan tubuh kembangnya anak, pada lingkungan sekolah, penanaman pendidikan karakter lebih kompleks. Anak-anak dituntut belajar berperilaku dalam menghayati, mengamalkan nilai dan norma serta akhlak mulia. Penanaman dan pembiasaan dalam menanamkan nilai-nilai luhur di lingkungan sekolah harus terintergrasi dalam proses pembelajaran pada setiap mata pelajaran terutama pada pembelajarna biologi. Pembiasaan dan menciptakan lingkungan yang kondusif serta menjadi figure bagi peserta didik adalah pekerjaan yang tidak mudah. Sekolah baik di perkotaan atau di pedesaan barangkali sudah sering dan terbiasa memberikan pelajaran pendidikan karakter. Namun hal ini seringkali lebih dominan aspek pengenalan atau pemahaman (kognitif). Yang sulit adalah bagaimana penghayatan dan pengamalannya (Anwas, 2010). Hasil wawancara yang dilakukan kepada siswa menunjukkan bahwa guru belum menunjukkan perilaku yang baik karena ketika proses pembelajaran berlangsung, guru sering menggunakan smartphonenya dan siswa diminta untuk mengerjakan tugas agar guru leluasa mengakses internet. Guru juga tidak pernah mengontrol penggunaan internet yang diakses oleh siswa ketika proses pembelajaran berlangsung. Menurut siswa, guru juga sering Selfie dan diposting ke akun media sosial. Ketika berkumpul dengan sesama rekan guru, guru juga jarang berkomunikasi dengan menatap langsung lawan bicaranya, guru lebih memilih menggunakan smartphone ketika berkomunikasi.

Guru membantu dalam membentuk watak peserta didik dengan cara memberikan keteladanan, cara berbicara atau menyampaikan materi yang baik, toleransi, dan berbagai hal yang terkait. Keteladanan guru kepada siswa dalam menanamkan nilai-nilai karakter menjadi suatu hal yang sangat urgen dalam rangka menghadapi era globalisasi. Penyelenggaraan pendidikan karakter menjadi satu hal yang multlak dilakukan di jenjang pendidikan manapun. Pemahaman yang mendalam dari praktisi pendidikan sangat ditekankan dalam usaha membentuk calon penerus bangsa tangguh di tengah lintasan perjalanan jaman dengan kemajuan teknologi yang semakin canggih yang diikuti dengan perubahan dan pergeseran nilai (Syarif, 2011).

Peran sekolah terutama guru dapat dikembangkan dengan penggunaan internet dalam pembelajaran biologi. Pemanfaatan internet dapat dilakukan di dalam maupun di luar kelas yang dapat diintegrasikan dalam proses pembelajaran biologi. Misalnya dengan meminta siswa untuk mencari artikel tentang kemajuan biologi yang nantinya dibahas bersama dalam kelas. Contoh pemanfaatan internet lainnya adalah dengan mencari video pembelajaran kemudian guru melakukan praktikum di luar kelas setelah melihat video tersebut. Guru dituntut untuk bijak menggunakan internet dalam pembelajaran biologi sehingga proses pembelajaran berjalan dengan baik dengan tidak menghilangkan karakter bersahabat/komunikatif. 


\section{KESIMPULAN}

Karakter bersahabat/komunikatif siswa masih tergolong rendah karena penggunaan internet belum berdampak positif kepada siswa. Siswa memaanfaatkan internet untuk mengakses media sosial seperti facebook, Line, Whatsapp, Instagram, Youtube, dan game online. Siswa ketika kumpul dengan temannya lebih focus mengakses internet daripada berkomunikasi langsung. Sekolah sudah membuat aturan untuk tidak menggunakan handphone ketika di sekolah, akan tetapi peraturan ini tidak serius diterapkan oleh sekolah karena masih banyaknya siswa yang menggunakan handphone di sekolah. Peranan guru juga kurang maksimal dalam menanamkan karakter bersahabat/komunikatif. Guru juga lebih memilih untuk mengakses internet ketika proses pembelajaran biologi berlangsung. Penanaman nilai karakter bersahabat/komunikatif dibutuhkan peran orang tua. Peranan orang tua juga belum maksimal untuk membentuk karakter ketika siswa berada di rumah. Orang tua membolehkan siswa mengakses internet dan tidak ada batasan waktu dalam penggunaannya sehingga komunikasi langsung antara orang tua dan siswa tidak terjalin dengan baik.

\section{UCAPAN TERIMA KASIH}

Ucapan terima kasih peneliti ucapkan kepada DRPM Kemenristek Dikti yang telah mendanai penelitian ini. Terima kasih juga kepada SMA di Kabupaten Labuhanbatu Utara yang telah menerima peneliti dengan baik untuk melakukan penelitian di sekolah.

\section{DAFTAR PUSTAKA}

Anwas, M.Oos. 2010. Televisi Mendidik Karakter Bangsa: Harapan dan Tantangan. Jurnal Pendidikan dan Kebudayaan. Vol 16: (2).

Fahoni Achmad. Desstya Anatri. 2017. Interpersonal Communication of The Principal As Efforts To Develop Character Education. The Progressive and Fun Education Seminar

Katilmis, A., Eksi, H., Öztürk, C. 2011. Efficiency of Social Studies Integrated Character Education Program. Educational Sciences: Theory \& Practice. 11 (2): 854-859.
Mulawarman., Nurfitri A.D. 2017. Perilaku Pengguna Media Sosial beserta Implikasinya Ditinjau dari Perspektif Psikologi Sosial Terapan. Buletin Psikilogi. Vol 25 (1). 36-44.

Nasrullah, R. (2015). Media sosial (perspektif komunikasi, budaya, dan sosioteknologi). Simbiosa Rekatama Media. Jakarta

Noviandari, L. 2015. Statistik Pengguna Internet dan Media Sosial Terbaru. Dikutip dari https://id.techinasia.com/

Prigunanto, Ilham. 2015. Pengaruh Sosial Media Terhadap Tingkat Kepercayaan Bergaul Siswa . Jurnal Penelitian Komunikasi dan Opini Publik Vol. 19(2) : 101 -110. 